\section{Contemporary learning or E-Learning in physiotherapy, pre and post COVID-19: Short communication}

\author{
Mohammed Suhail ${ }^{1 *}$, Sharath $\mathrm{C}^{2}$ and Akhil Mathew ${ }^{3}$ \\ ${ }^{1}$ Associate Professor, CEC-IAP, Principal, Kanachur College of Physiotherapy, Mangalore, India \\ ${ }^{2}$ Assistant Professor, BOS Member- RGUHS, Vice Principal, SDCPT, Mangalore, India \\ ${ }^{3}$ Assistant Professor, Physiotherapy, RGUHS, Bangalore, India
}

Since December 2019, an outbreak of novel corona virus disease was reported in Wuhan, which has subsequently affected more than 160 countries worldwide. The ongoing outbreak has been declared as a pandemic by WHO, a global public health emergency. Several countries are successfully fighting with the pandemic by taking strict measures like nationwide lockdown or by sequestering the areas that were suspected of having risk of community spread. The corona virus pandemic has upended our educational system worldwide [1-3].

The academic calendar all over the world has been disturbed as a result of lockdown. Even after lockdown it would take probably many more months for universities, colleges and schools to reinstate. Caught in the turmoil, some parts of urban Indian education system have turned towards delivery of education via internet or online education. The NCAER skills report 2018 discussed the immense potential of online learning, conversely as complementary to more traditional methods. Centuries old, lecture based approaches, institutional biases, and outmoded classrooms changed. Covid 19 has become an impetus for educational institutions worldwide to search for innovative solutions in a relatively short duration. In the prevailing situation, online education is turning out as an alternative to traditional modes $[2,4,5]$.

Contemporary/E-learning prepares students across all curriculum and learning stages with skills and potential to flourish in a rapidly changing and interlinked world. It connects students and engages their sense of inquisitiveness. E-teachers know and understand the needs and talents of their students. They are trained, flexible and select from a wide range of effective teaching strategies based on need. The new learning environment and resources galvanize students to be leaders of their independent learning. Thus students collaborate and use critical and creative thinking to solve complex problems and become apprehensive and sentient global citizens [4-6]. In physiotherapy, apart from traditional institution based

\author{
More Information \\ *Address for Correspondence: Mohammed \\ Suhail, Assistant Professor, Physiotherapy, \\ RGUHS, Bangalore, India, \\ Email: unitedkerala14@gmail.com \\ Submitted: 11 May 2020 \\ Approved: 16 May 2020 \\ Published: 18 May 2020 \\ How to cite this article: Suhail M, Sharath C, \\ Mathew A. Contemporary learning or E-Learning \\ in physiotherapy, pre and post COVID-19: Short \\ communication. J Nov Physiother Rehabil. 2020; \\ 4: 009-010. \\ DOI: 10.29328/journal.jnpr.1001030 \\ Copyright: @ 2020 Suhail M, et al. This is \\ an open access article distributed under the \\ Creative Commons Attribution License, which \\ permits unrestricted use, distribution, and re- \\ production in any medium, provided the original \\ work is properly cited. \\ D) Check for updates \\ OPEN ACCESS
}

learning, there implies a need for technological inputs and E-learning as a need to develop critical, creative thinking and reasoning. These technological arrays do provide better concepts and understanding regarding academics and practice [6]. As physiotherapy is advancing and growing in academics, research and practice, the need for an interlinking platform through which learning becomes unconditional and globally accessible was never addressed. Covid- 19 lockdown and strategies imposed us to think apart from institutional mode, ostensibly got a worldwide acceptance.

Research suggests that online learning has been shown to increase retention of information, and take less time. On average, students retain $25 \%$ - $60 \%$ more information when learning online compared to only $8 \%-10 \%$ in a classroom. E-learning requires $40 \%-60 \%$ less time to learn and understand than in a traditional setting, because students can learn at their own pace, re-reading, skipping or accelerating through concepts as they choose. Contemporary learning or E-learning at present situation is intended to have the desired effect such as physical distancing, schedule flexibility, cost effective, fast learning, course variety, boost memory, reasoning and innovative teaching $[2,4]$.

Adoption of online learning will continue to persist post pandemic, and how such a shift would impact the worldwide education market should be studied. Some believe that the unplanned and rapid move to online learning with no training, insufficient bandwidth, and inadequate preparation will result in a poor user experience that is deleterious to 
sustained growth $[5,8]$. The current crisis has acted as a thwack to encourage digital education among physiotherapy institutions. However, to achieve its prospective in the long run, physiotherapy institutions and universities should implement a digital platform, training as well as a curriculum regulation. "We believe that, the integration of information technology, E-learning in education will be further accelerated and eventually transpire to an integral component of physiotherapy education and practice".

\section{References}

1. Ali UTI, Mathew A, Fathima S. Role of physiotherapy in improving respiratory and functional outcomes among COVID-19 survivors Short communication. Int J of Allied Med Sci Clin Res. 2020; 8: 83-84.

2. https://education.nsw.gov.au/teaching-and-learning/school-learningenvironments-and-change/future-focused-learning-and-teaching.
3. Dey M, Mathew A. Covid-19 lockdown, a major risk factor prevailing to physical inactivity and musculoskeletal disorders: short communication. Int J of Allied Med Sci and Clin Res. 2020; 8: 164-165.

4. https://www.teachermagazine.com.au/articles/teaching-incontemporary-learning-spaces.

5. Küppers B, KerberF, MeyerU, SchroederU. Beyond Lockdown:Towards Reliable e-Assessment. In: Igel C, Ullrich C, (Hrsg.), Bildungsräume 2017. Gesellschaft für Informatik, Bonn. 2017; 191-196.

6. Peacock S, Hooper J. E-learning in physiotherapy education, J Physiotherapy. 2007.

7. Fathima S, Jaya P. Effect of chronic smartphone use on upper extremity muscle activity and pain threshold. Int $\mathrm{J}$ of Allied Med Sci and Clin Res. 2020; 8: 85-90.

8. Segrave S, Holt D. Contemporary Learning Environments: Designing e-Learning for Education in the Professions, Distance Education. 2003; 24: 7-24. 